\title{
UNUSUAL SPINEL-GARNET LHERZOLITE XENOLITHS FROM BASALT IN EASTERN CHINA: CONSTRAINTS ON THE LATE-TERTIARY THERMAL STRUCTURE OF THE UPPER MANTLE.
}

\author{
Jin, ${ }^{(1,2)}$ Z-M.; Green II, ${ }^{(1)}$ H.W.; Borch, ${ }^{(1)}$ R.S. and Tingle, ${ }^{(1)}$ T.N. \\ (1) Department of Geology of California, Davis, CA 95616 USA; (2) Department of Geomechanics, University \\ China University of Geosciences, Wuhan 430074, PRC.
}

\begin{abstract}
Although garnet peridotite xenoliths are common from kimberlite, they are quite rare in basalts. Xenoliths in which coexisting spinel and garnet are found are even more rare. We have identified spinel-garnet lherzolite xenoliths from three localities in Eastern China: A Pliocene alkalic basalt in Nushan County, Anhui Province; a Plio-Pleistocene nephelinite basalt and limburgite in Mingxi County, Fujiang Province; and a Plio-Pleistocene nephelinite tuff in Zhejiang Province. The first locality is in close proximity to the Tangcheng-Lujiang deep fault and the other two are associated with the deep fracture system of the south-east coast of China. The thickness of the crust in these regions is $31-33 \mathrm{~km}$.

These special xenoliths are very similar in both localities. They are $5-20 \mathrm{~cm}$ in diameter and all are five-phase peridotites (olivine-enstatite-diopside-garnet-spinel) with the following volume proportions: Olivine (55-65\%); Orthopyroxene (20-30\%); Clinopyroxene (10-15\%); Garnet (3-6\%); Spinel (2-5\%). They have coarse-tabular textures with a distinct foliation defined by elongated olivines and pyroxenes and aligned spinels. The garnets are round and lacking in inclusions; in most cases they have a well-developed thin, fibrous, kelyphitic reaction rim consisting of pale brown translucent spinel and pyroxene. Examination of the dislocation microstructure of the olivines using the oxidation decoration technique also found them to be very similar. In both localities, the olivines of these xenoliths, like the more-abundant spinel peridotites, show evidence of three stages of plastic deformation: (i) Wide, straight, (100) subgrain boundaries induced by low stress deformation; (ii) very narrow (100) boundaries induced by higher stress deformation; (iii) local development of $\{110\}$ slip bands produced by still higher stresses associated with xenolith extraction from the mantle by the magma (Jin et al., 1989).

All phases of these rocks are homogeneous in chemical composition. Analyses were determined with a Cameca electron microprobe. A representative example from each locality is presented in Table I:
\end{abstract}

TABLE 1: Composition (wt \%) of 5-phase Lherzolite Xenoliths from Eastern China MINGXI \#M-3 NUSHAN \# N-3

\begin{tabular}{lrrrrr|rrrrr} 
& \multicolumn{1}{c}{$\mathrm{O}$} & $\mathrm{Opx}$ & \multicolumn{1}{c}{$\mathrm{Cpx}$} & \multicolumn{1}{c}{$\mathrm{Ga}$} & \multicolumn{1}{c}{$\mathrm{Sp}$} & \multicolumn{1}{c}{$\mathrm{O}$} & \multicolumn{1}{c}{$\mathrm{Opx}$} & $\mathrm{Cpx}$ & \multicolumn{1}{c}{$\mathrm{Ga}$} & $\mathrm{Sp}$ \\
\cline { 2 - 10 } $\mathrm{SiO}_{2}$ & 40.77 & 54.39 & 51.76 & 41.76 & 0.11 & 40.80 & 53.64 & 51.03 & 42.17 & 0.12 \\
$\mathrm{TiO}_{2}$ & 0.11 & 0.13 & 0.43 & 0.17 & 0.26 & 0.01 & 0.16 & 0.48 & 0.16 & 0.21 \\
$\mathrm{Al}_{2} \mathrm{O}_{3}$ & - & 3.27 & 6.14 & 23.26 & 49.20 & - & 5.65 & 7.53 & 22.34 & 56.42 \\
$\mathrm{Cr}_{2} \mathrm{O}_{3}$ & 0.02 & 0.50 & 1.15 & 1.27 & 17.09 & 0.02 & 0.36 & 0.69 & 1.04 & 9.01 \\
$\mathrm{FeO}$ & 9.39 & 6.38 & 3.15 & 7.71 & 11.88 & 10.49 & 7.06 & 3.90 & 7.69 & 11.76 \\
$\mathrm{MnO}$ & 0.13 & 0.12 & 0.05 & 0.36 & 0.09 & 0.13 & 0.16 & 0.13 & 0.45 & 0.08 \\
$\mathrm{MgO}$ & 49.27 & 33.77 & 16.07 & 20.54 & 20.22 & 48.66 & 32.52 & 16.33 & 21.86 & 21.29 \\
$\mathrm{NiO}$ & 0.38 & - & - & - & - & 0.38 & - & - & - & - \\
$\mathrm{CaO}$ & 0.08 & 0.79 & 18.41 & 5.07 & 0.33 & 0.11 & 0.22 & 17.97 & 4.87 & 0.39 \\
$\mathrm{Na} 2 \mathrm{O}$ & - & 0.17 & 1.73 & - & 0.01 & - & - & .70 & 0.06 & 0.10 \\
& & & & & & & & & \\
Total & 100.05 & 99.52 & 99.06 & 100.16 & 99.14 & 100.60 & 100.82 & 99.76 & 100.64 & 99.38 \\
\hline
\end{tabular}

The chemical compositions of these lherzolites are similar to the few published analyses of other 5-phase peridotites. The correspondence with a xenolith from the Massif Central in France (Berger and Brousse, 1976; Berger, 1977) is particularly striking because of the similarly high $\mathrm{Al}_{2} \mathrm{O}_{3}$ and low $\mathrm{Cr}_{2} \mathrm{O}_{3}$ contents. A spinel-garnet xenolith from the Pali-Aike volcanic field, Chile (Skewes and Stern, 1979; Stern et al., 1984) and one from a kimberlite in New South Wales, Australia (Fergusen et al., 1977) have significantly more $\mathrm{Cr}_{2} \mathrm{O}_{3}$ in the spinels and those from kimberlite in Lesotho, S. Africa (Nixon and Boyd, 1973) are very much richer in $\mathrm{Cr}_{2} \mathrm{O}_{3}$ and lower in $\mathrm{Al}_{2} \mathrm{O}_{3}$. 
Temperatures and pressures of equilibration were estimated for specimens M-3 and M-4 (Mingxi) and N-3 (Nushan) using the geothermometer of Nickel and Green (1985) and the geobarometer of Bertrand and Mercier (1985). The calculated conditions of equilibration were: \#M-3: $1020^{\circ} \mathrm{C}, 1.8 \mathrm{GPa}(62 \mathrm{~km})$; \#M-4: $1100^{\circ} \mathrm{C}, 2.62 \mathrm{GPa}(85 \mathrm{~km})$; \#N-3: $1100^{\circ} \mathrm{C}, 1.9 \mathrm{GPa}(63$ $\mathrm{km})$. These conditions are consistent with stable coexistence of garnet and spinel in chrome-poor peridotite (O'Neill, 1981). To facilitate direct comparison between these xenoliths and those from the literature, we also used the same thermobarometric method to calculate the conditions of equilibration of the 5-phase peridotites from the Massif Central, Lesotho, Pali-Aike, New South Wales, and another garnet-spinel peridotite from Bow Hill, Tasmania for which analysis of the spinel has not been published (Sutherland et al., 1984). The last three of these xenoliths all lie within the range of our temperature and pressure determinations; those from the Massif Central are hotter and deeper $\left(1270^{\circ} \mathrm{C} ; 77 \mathrm{~km}\right)$ and those from Lesotho are much colder and much deeper $\left(\sim 900^{\circ} \mathrm{C} ; 115 \mathrm{~km}\right)$. Thus, all of these 5-phase lherzolites except those from South Africa plot on an elevated geotherm whereas those from Lesotho lie on a typical $40 \mathrm{~mW} / \mathrm{m}^{2}$ continental geotherm.

Eastern China has more than 7 localities of garnet peridotite from basalt including at least three localities of spinel-garnet lherzolite. Thus, this area may be a particularly useful region for determination of the structure and composition of this critical depth region of the subcontinental mantle. The opportunity to determine precise temperature and pressure conditions for these unusual xenoliths also will allow us to anchor the geotherm for these regions and thereby assign pressures to spinel lherzolite xenoliths for which only accurate temperatures can be directly determined.

\section{REFERENCES}

Berger, E. (1977) Sur la présence d'une lherzolite à grenats en enclave dans le basalte alcalin de la Vestide du Pal (Ardèche): Conditions d'équilibre, implications pétrogénétiques et géotectoniques. C. R. Acad. Sci. Paris, Fr., D. 284, 709-712.

Berger, E.and Brousse, R. (1976) Une lherzolite à grenats du pipe d'Eglazine (Lozere, France) stabilisee à $1400^{\circ} \mathrm{C}$ et $30 \mathrm{~kb}$. C. R. Acad. Sci. Paris. Fr., D. 282, 1477-1480.

Bertrand, P. B. and Mercier, J-C. (1985) The mutual solubility of coexisting ortho- and clinopyroxene: towards an absolute geothermobarometer for the nature system. Earth Planet. Sci. Lett. 76, 109-122.

Ferguson, J., Ellis, D-J., and England, R. N. (1977) Unique spinel-garnet lherzolite inclusion in kimberlite from Australia. Geology 5, 278-280.

Jin, Z.-M., Green II, H. W. and Borch, R. S. (1989) Microstructures of olivine and stress in the upper mantle beneath eastern China. Tectonophysics 169, 23-50.

Nickel, K. G. and Green, D. H. (1985) Experimental geothermobarometry for garnet peridotites and implications for the nature of the lithosphere, kimberlite and diamonds. Earth Planet. Sci. Lett. 73, 158-170.

Nixon, P. H. and Boyd, F. R.(1973) Petrogenesis of the granular and sheared ultrabasic nodule suite in kimberlites. Lesotho Kimberlites by Nixon, P. H. (Editor) 48-56.

O'Neill, H. St.C (1981) The transition between spinel lherzolite and garnet lherzolite and its use as a geobarometer. Contrib. Mineral. Petrol. 77, 185-194.

Skewes, A. and Stern, C. R. (1979) Petrology and geochemistry of alkali basalt and ultramafic inclusions from the Pali-Aike volcanic field in Southern Chile and the origin of the patagonian plateau Lavas. J. Volcanol. Geotherm. Res. 6, 3-25.

Sutherland, F. L., Hollis, J. D., and Barron, L. M. (1984) Garnet lherzolite and other inclusions from a basalt flow, Bow Hill, Tasmania. Kimberlites II: The Mantle and Crust Mantle Relationships. Kornprobst, J. (Editor), 145-160, Elsevier, Amsterdam.

Stern, C. R., Saul, S., Skewes, M. A. and Futa, K. (1989) Garnet peridotite xenoliths from the Pali-Aike alkali basalts of southernmost South America. Kimberlites and Related Rocks, Volume 2, Geol. Soc. Australia Spec. Publ. 14. Ross, J. et al. (Editors). 735-744. 